\title{
Evaluation of Some Date Palm Male Types Using Morphological and Molecular Markers
}

\author{
A.M. Ibrahim* ${ }^{*}$ M.B. El-Sabrout* and Nahla A.A. ** \\ *Pomology Deptartment Faculty of Agriculture, Alexandria \\ University, and ${ }^{* *}$ Fruit breeding Department, Horticulturel \\ Research Institute, Agricultural Research Centre, Cairo, Egypt.
}

\begin{abstract}
TIVE LOCATIONS of mature male palm trees belong to three governorates (Alexandria, Behira and Sohage) were subjected to evaluate some physical characteristics and certain chemical constituents to determine a superior type as promising ones for pollinating the female flowers to incorporate those types in the breeding programs.

It is obvious that locations of El-Behira governorate recorded almost the highest value for morphological characteristics. The same trend was observed for pollen viability and mineral content. The Tahta location which belongs to sohage governorate usually showed a high content of carbohydrates. On the other hand, males of Rasheed (El-Behira governorate) recorded the highest protein percentages. However, there were no significant differences between those males and the other males that grown in the rest of locations. Amino acids content varied from one location to another. Moreover, one primer of RAPD marker (OPC 13) has the potential to identify three genotypes and only four primers have the ability to characterize four genotypes.
\end{abstract}

Date palm (Phoenix dactylifera L.) is one of the most important and oldest fruit tree, it has been cultivated by man since antiquities. It is considered to be the oldest tree with a great genetic diversity (Popenoe, 1973, Zohary and SpiegelRoy, 1975).

In Arab Republic of Egypt, such a crop always ranking superior over many other fruit crops due to the nutritional value of the fruits, which makes it available to the consumers at a relatively low cost. The total area devoted to date palm increased gradually until it reached about 56 thousand feddans occupied by about 6.6 million female trees produce about $14 \%$ of the overall fruit production (Ibrahim \& Kholif, 2004 and Badawi et al., 1994). The total number of female date palm trees reached about 12039424 trees were cultivated in 86787 feddans produce about 1313696 ton (Agricultural Statistics, 2008). As a matter of fact, dates are dioecious; i.e. male flowers are born on a given tree and female flowers born on a separate one, and pollination is usually accomplished by wind, however, under cultivation the female flowers are pollinated by artificial means (hand). However, artificial hand pollination represents a great task for the date growers, and such a practice should be done using the most viable pollens in order to get the highest fruit set and highest gross yield (El-Hammady et al., 1977, Khalifa et al., 1980, El-Makhtoun, 1981 and Hamdy, 1982). 
In date palm breeding programs, cultivars identification still relies on morphological characteristics. However, many cultivars can not be rapidly distinguished by morphological indices, particularly if they are closely related. Furthermore, phenotype identification based on morphological traits is subject to environmental variation (Nielson, 1985). The field of molecular biology has provided tools suitable for rapid and detailed genetic analysis of higher organisms including agriculture species (Williams et al., 1990). The most fundamental of those tools are DNA markers. RAPD (Randomly Amplified Polymorphic DNA marker) method, based on amplification of multiple, random segments of the genome using arbitrary primers (Welsh \& McClelland, 1990; and Williams et al., 1990). The above mentioned technique was utilized to detect phylogenetic relationships between some selected male types using morphological and molecular markers.

The aim of the present study is to evaluate the effect of zone of plantation on some physical characteristics and certain chemical constituents of the spathes, pollens and estimate the genetic relatedness of these genotypes using RAPD markers and subsequently, determine the superior types as promising ones for pollinating the female flowers, to incorporate those types in the breeding programs.

\section{Materials and Methods}

The selected types were grown at private orchards located at El-Nahda, Alexandria Governorate, Rasheed and Kafer El-Dawar, Behira Governorate, ElMaragha, Tema and Tahta, Sohage Governorate.

\section{Morphological and chemical studies}

Physical characteristics

At the flowering time (middle of March to the end of April), four mature spathes were randomly collected from each male tree type (thirty years old), to measure some morphological characteristics of spathes, inflorescences, strands and pollens in the laboratory of Pomology Department, Faculty of Agriculture, Alexandria University. The following characteristics were measured and recorded:

\section{Spathe}

1- The average weight of the spathe (gm) 2-The average width of the spathe $(\mathrm{cm})$ $3-$ The average length of the spathe $(\mathrm{cm})$ 4-The average weight of the spathe cover (gm)

\section{Inflorescence}

The average weight of the inflorescence for each male type (gm), also, the average width and length for the inflorescence of each selected type were measured $(\mathrm{cm})$ and recorded. 
Strand

Some strands from each inflorescence that represent each male were separated and subjected to determine

1- Average length $(\mathrm{cm}) \quad 2-$ Average number of strands per inflorescence

3 - Average number of flowers per strand

\section{Pollen characteristics}

1-Average pollen weight per spathe was recorded according to Nasr et al. (1986). 2 - Viability determination, two general methods assaying pollen viability were used A-Germination test and B- Microscopic examination following staining test. Both of these techniques were achieved according to Ibrahim (1989)

\section{Chemical determination}

Pollen grains samples were taken to study some biochemical properties in the Laboratory of Pomology Department and the Biotechnology Laboratory of the Horticulture Research Institute.

Mineral content: For determination nitrogen, phosphorus and potassium, 0.1 $\mathrm{gm}$ of dried pollen grains materials were digested by sulphuric acid and hydrogen peroxide according to Evenhuis and DeWaard (1980).

Carbohydrates: Total sugars were determined according to Malik and Singh (1980). Reducing sugars and starch were determined by Dubois et al., (1956). Non reducing sugars were calculated by the difference between the total sugars and the reducing sugars. Total carbohydrates were calculated as a summation of the total sugars and other carbohydrate constituents. The results were expressed as $\mathrm{gm} / 100 \mathrm{gm}$ or percent on dry weight basis

Proteins: Crude protein $(\mathrm{N} \times 6.25)$ was determined according to the A.O.A.C method (1981).

Amino acid content: Two steps were achieved to determine the amino acid content

\section{a- Acid hydrolysis (sample preparation)}

Seventy-five milligrams of each composite sample of pollen grains were treated with $10 \mathrm{ml}$ of constant-boiling HCL containing mercopto-ethanol $(5 \mu \mathrm{l} /$ $10 \mathrm{ml}$ acid) in hydrolysis tube which were kept in a vacuum oven at $110^{\circ} \mathrm{C}$ for 22 hrs and were cooled to the room temperature. The amino acid content in protein hydrolyzate was detected using Amino Acid Analyzer according to Moore et al., (1958). The concentrations of amino acid were calculated as grams per 100 grams of protein or percent on dry weight basis.

\section{b-Separation}

Backman Amino Acid Analyzer Model 119CL was used for amino acid determination in pollen grains materials of the tested date palm genotypes. 
DNA fingerprint

Total genomic DNA was extracted from young and fresh leaves of date palm tested genotypes, using modified CTAB protocol (Porebski et al.,1997). RAPD fragments were amplified according to (Machado et al., 1996). Amplification reaction for RAPD consisted of $1.5 \mathrm{mM} 10 \mathrm{X}$ buffer, $1.5 \mathrm{mM} \mathrm{MgCl}_{2}, 100 \mu \mathrm{M}$ dNTPs $(25 \mu \mathrm{M}$ each), $0.2 \mu \mathrm{M}$ primer, $1 \mathrm{U}$ Taq polymerase, $50 \mathrm{ng}$ of DNA and sterile water up to $25 \mu \mathrm{l}$. RAPD amplification was conducted as follow: an initial step at $94^{\circ} \mathrm{C}$ for $5 \mathrm{~min}$. 40 cycles for each cycle $1 \mathrm{~min}$. at $94^{\circ} \mathrm{C}, 1 \mathrm{~min}$. at $37^{\circ} \mathrm{C}$ and $2 \mathrm{~min}$. at $72^{\circ} \mathrm{C}$ and final extension step at $72^{\circ} \mathrm{C}$ for $5 \mathrm{~min}$.

\section{Statistical analysis}

The data obtained throughout this study were statistically analyzed by the analysis of variance as a complete random design as explained by Snedecor and Cochran (1981).

\section{Results and Disscussion}

Morphological and Physical Characteristics

Pollen characteristics

The recorded data Table 1 of both seasons clearly showed, males of Kafer ElDawar recorded the lowest values of pollen weight per spathe in the first and second seasons. Meanwhile, the other males had intermediate average of pollen grains weight with no significant difference between each other in most cases.

TABLE 1. Weight of the pollen grains per spathe and pollen viability tests of different date palm male types during 2009 and 2010 seasons.

\begin{tabular}{|c|c|c|c|c|c|c|}
\hline \multirow{3}{*}{ Location } & \multicolumn{3}{|c|}{2009} & \multicolumn{3}{|c|}{2010} \\
\hline & \multirow{2}{*}{$\begin{array}{c}\text { Pollen } \\
\text { weight / } \\
\text { Spathe } \\
\text { (gm) }\end{array}$} & \multicolumn{2}{|c|}{ Pollen viability } & \multirow{2}{*}{$\begin{array}{c}\text { Pollen } \\
\text { weight / } \\
\text { Spathe } \\
\text { (gm) }\end{array}$} & \multicolumn{2}{|c|}{ Pollen viability } \\
\hline & & $\begin{array}{c}\text { Stained } \\
(\%)\end{array}$ & $\begin{array}{c}\text { Germinated } \\
(\%)\end{array}$ & & $\begin{array}{c}\text { Stained } \\
(\%)\end{array}$ & $\operatorname{Germinated}(\%)$ \\
\hline El Nahda & 24.87 & 94.00 & 66.18 & 28.55 & 93.44 & 65.49 \\
\hline Rasheed & 17.85 & 94.41 & 69.12 & 19.18 & 94.27 & 71.72 \\
\hline Kafer EL-Dawar & 12.37 & 89.34 & 54.47 & 16.65 & 88.54 & 55.66 \\
\hline ELmaragha & 17.00 & 93.00 & 59.68 & 18.48 & 93.89 & 60.70 \\
\hline Tema & 13.00 & 88.60 & 62.47 & 15.37 & 84.72 & 63.67 \\
\hline Tahta & 20.00 & 90.49 & 61.23 & 22.65 & 91.26 & 59.36 \\
\hline $\operatorname{LSD}(0.05)$ & 4.33 & 3.75 & 5.45 & 5.82 & 2.39 & 3.03 \\
\hline
\end{tabular}

For pollen viability, it is obvious that males of Rasheed recorded significantly the higher values in both seasons (69.12 and $71.72 \%$ respectively). In the contrary males of Tema recorded the lowest value in both season (88.60and $84.72 \%$ respectively) when direct germination test used (Table 1). However, the viability using the acetocarmine staining test revealed that males grown in Rasheed had significantly the highest viability percentage in both season (94.41 and $94.27 \%$ respectively).

Egypt. J. Hort. Vol. 40, No.1 (2013) 


\section{Spathe}

Average weight of the spathes of the different male types were highest for those male types selected from Rasheed and lowest for males from Tema region (Table 2) in the second season. Moreover, the data of 2009 and 2010 seasons revealed that the males grown in Rasheed area had significantly higher average spathe width (19.25 and $18.25 \mathrm{~cm}$, respectively) than all the other males grown in the other zones. Meanwhile, Males of Tema gave significantly lowest average width in the both seasons (11.50 and $12.00 \mathrm{~cm}$ respectively).

\section{Inflorescence}

The data of Table 2 clearly show that the males of El-Nahda had significantly the highest average weight of the inflorescence in both seasons ( 1.36 and $1.40 \mathrm{~kg}$ respectively) as compared with the other males that grown in the rest of locations. However, the lowest value was recorded by Tema region. On the other hand, the males selected from Rasheed gave the higher values of the average inflorescence width in both 2009 and 2010 seasons $(18.73$ and $16.25 \mathrm{~cm}$ respectively).

It was obvious that males of El-Nahda recorded significantly the highest average of the inflorescence length in both seasons $(105.50$ and $99.25 \mathrm{~cm}$ respectively) in comparison with those of the other males of different locations. On the contrary, males of Rasheed gave the lowest inflorescence length in both seasons (65.25 and $66.75 \mathrm{~cm}$ respectively)

\section{Strand}

It is clear that the males grown in Kafer El-Dawar produced the highest significantly average strand length in both experimental seasons (23.50 and $24.85 \mathrm{~cm}$ respectively) as compared with the obtained values of the other male types. In the meantime males of Tahta had significantly the lowest strand length than those other male types in both seasons (14.30 and 15.15). Moreover, in ElNahda a significantly highest number of strand per inflorescence (260 and 255 strands respectively) was observed, however, there were no significant differences regarding such a trait between males of El-Nahda and those of Tahta, Kafer El-Dawar, El-Maragha and Rasheed in the first seasons. Almost the same trend was noticed in the second season (table 2). Moreover, the highest number of flower per strand was recorded by the males of El-Nahda (74.66 and 75.01 respectively) while males of Rasheed gave the lowest value in both seasons (49.95 and 52.21. respectively).

The results relating to morphological characteristics are in harmony with those obtained by Ashour et. al., (2004), Ibrahim \& Kholif (2004); Alsaikhan (2006) and Rabie (2007). It's clear that the great variation regarding the physical characteristics of studied male types could be due to the differences between the genetic constituents of the different male types. 
Chemical studies

Carbohydrates

As shown in Table 3, pollens of the male type of Tahta contained the highest percentage of starch in 2009 and 2010 seasons (11.32 and $11.94 \%$ respectively) and the differences were statistically significant as compared with those of the other male types. Meanwhile, the total sugars percentages in the pollens of the different studied date male showed that a highest total sugar percentages in 2009 for pollens of the males that grown in tahta $(6.20 \%)$ while, the highest value recorded in 2010 season was found in the pollen of the males that grown in Rasheed (7.85\%).

In the second season, pollens of the male type grown in Rasheed contained the highest percentage of reducing sugars $(4.24 \%)$, the statistical analysis showed that the differences between such a value and those of the rest of males were highly significant. However, non reducing sugars revealed that pollens of Rasheed male type recorded the greatest content $(3.61 \%)$ in the second season, the differences were significant in comparison with those males of Kafer ElDawar, Tema and Tahta.

Regarding the percentages of total carbohydrates in the pollens of the studied males, it is obvious that pollen of Tahta male type contained the highest value (17.25 and $17.04 \%$ ), in 2009 and 2010 seasons respectively. Bacha et al. (1997) determined the chemical compositions of pollen grains of 13 date palm male types and found that the starch percentages ranged between 8.10 and 9.24, carbohydrates content ranged from 10.5 to $13.1 \%$., reducing sugars ranged from 0.053 to $0.177 \%$ and non-reducing sugar in date ranged from 1.18 to $3.89 \%$. Moreover, Hassan (2011) studied the chemical composition and nutritional value of palm pollen grains; he reported that the value of the carbohydrate content in the pollen was $13.41 \%$.

\section{Proteins}

As shown in Table 3 males of Rasheed recorded the remarkable highest protein percentages in both of the studied seasons (31.73 and $30.69 \%$ respectively). However, there were no significant differences between those males and the other males that grown in the other locations. Human and Nicolson (2006) found that, the value of crude protein content in the date palm pollens ranged between $12-16 \%$. Moreover, Campos et al. (2008) reported that protein content of pollen grains ranged between $10-40 \mathrm{~g} / 100 \mathrm{~g}$ dry weight. In addition, Hassan (2011) stated that the protein content of date palm pollens reached $31.11 \mathrm{~g} / 100 \mathrm{~g}$ dry weight of palm pollen grains.

\section{Mineral content}

The obtained data (Table 4) showed that pollens of Rasheed males had significantly highest nitrogen content in both seasons (5.08 and $4.91 \%$ respectively).

Egypt. J. Hort. Vol. 40, No.1 (2013) 


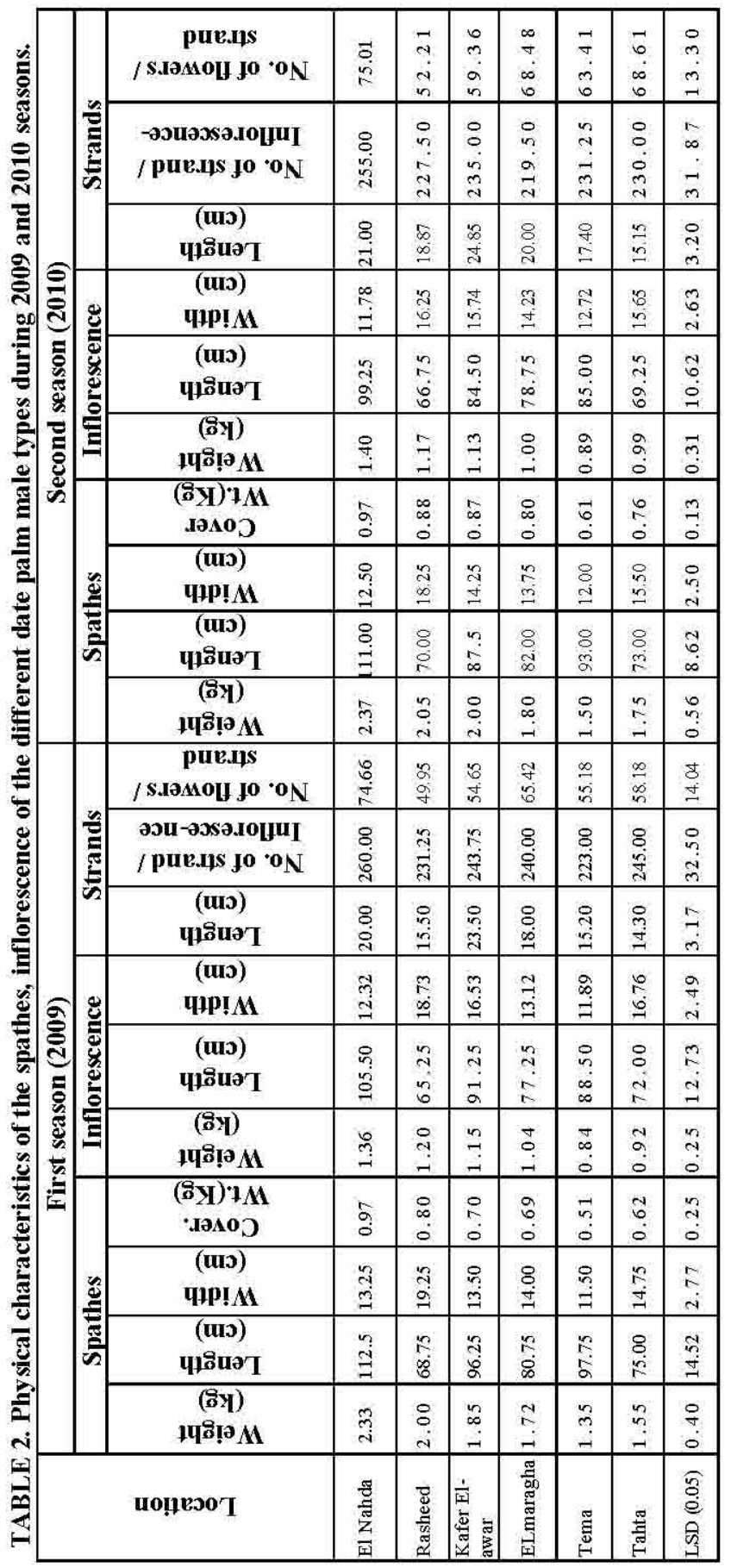




\begin{tabular}{|c|c|c|c|c|c|c|c|c|}
\hline \multirow{6}{*}{ 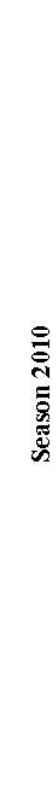 } & 产 & $\begin{array}{l}\infty \\
\stackrel{\text { ते }}{ }\end{array}$ & 兽 & $\begin{array}{l}\stackrel{n}{2} \\
\infty \\
\stackrel{\infty}{\rightarrow}\end{array}$ & ते & $\begin{array}{l}\overline{6} \\
\stackrel{0}{\Omega}\end{array}$ & 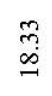 & 常 \\
\hline & 党 & $\begin{array}{l}8 \\
\dot{ \pm}\end{array}$ & $\begin{array}{l}8 \\
\dot{0} \\
\end{array}$ & $\stackrel{m}{\stackrel{m}{\Xi}}$ & $\stackrel{\text { I }}{\mathrm{I}}$ & $\begin{array}{l}\stackrel{0}{2} \\
\stackrel{n}{n}\end{array}$ & $\stackrel{\Xi}{\stackrel{\Xi}{\leftrightarrows}}$ & $\underset{\sim}{\stackrel{\infty}{-}}$ \\
\hline & 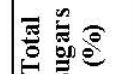 & $\begin{array}{l}\tilde{b} \\
\dot{n}\end{array}$ & $\stackrel{\infty}{\infty}$ & 号 & तु & $\stackrel{n}{f}$ & $\stackrel{\circ}{n}$ & $\stackrel{\overbrace{}}{\rightarrow}$ \\
\hline & 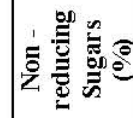 & $\stackrel{2}{m}$ & $\underset{\dot{m}}{\vec{r}}$ & 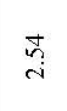 & $\stackrel{\infty}{\infty}$ & $\begin{array}{l}\tilde{n} \\
\text { ñ }\end{array}$ & $\begin{array}{l}\stackrel{n}{0} \\
i\end{array}$ & ণิ \\
\hline & 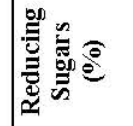 & $\begin{array}{l}0 \\
\text { n. } \\
i\end{array}$ & 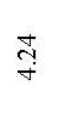 & $\stackrel{0}{9}$ & $\stackrel{\circ}{\text { S }}$ & $\stackrel{ }{9}$ & 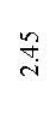 & $\stackrel{\circ}{=}$ \\
\hline & 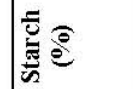 & $\stackrel{\text { ò }}{\infty}$ & $\stackrel{2}{7}$ & $\stackrel{\infty}{\alpha}$ & 곡 & $\bar{a}$ & $\stackrel{\text { ta }}{=}$ & $\stackrel{\infty}{\stackrel{-}{-}}$ \\
\hline \multirow{6}{*}{ 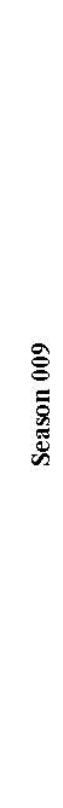 } & 醇 & $\begin{array}{l}\mathscr{0} \\
\ddot{\sim} \\
\dot{\sim}\end{array}$ & $\stackrel{m}{\stackrel{m}{m}}$ & $\begin{array}{l}\stackrel{2}{\sigma} \\
\stackrel{\sigma}{\sigma}\end{array}$ & $\stackrel{m}{=}$ & 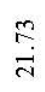 & $\begin{array}{l}\stackrel{\infty}{\circ} \\
\stackrel{0}{\rightarrow}\end{array}$ & $\stackrel{\tilde{n}}{n}$ \\
\hline & & $\begin{array}{l}2 \\
\stackrel{0}{g} \\
\end{array}$ & 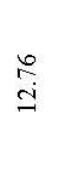 & $\begin{array}{l}\infty \\
\stackrel{\infty}{\infty} \\
\end{array}$ & $\stackrel{\circ}{\underset{I}{I}}$ & 尽 & 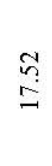 & $\begin{array}{l}\infty \\
\\
\end{array}$ \\
\hline & 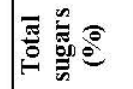 & 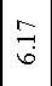 & 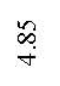 & $\vec{m}$ & $\begin{array}{l}\stackrel{\Delta}{\circ} \\
\ddot{n}\end{array}$ & 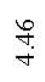 & జ్రి & $\stackrel{\infty}{\stackrel{\infty}{r}}$ \\
\hline & 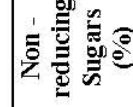 & $\begin{array}{l}\infty \\
\stackrel{\sim}{~}\end{array}$ & స్తే & in & $\vec{i}$ & $\underset{\sim}{\vec{j}}$ & $\stackrel{r}{i}$ & $\vec{\sigma}$ \\
\hline & 照 & $\vec{m}$ & $\tilde{\tilde{n}}$ & $\stackrel{\text { th }}{\mathrm{n}}$ & $\underset{\substack{\infty \\
\sim}}{ }$ & $\underset{n}{n}$ & $\underset{f}{f}$ & ઠू \\
\hline & 䇏 & $\underset{\substack{q \\
\sim}}{ }$ & $\vec{g}$ & $\begin{array}{l}6 \\
\infty \\
\infty\end{array}$ & $\stackrel{\leftrightarrow}{r}$ & $\underset{\infty}{\mathbb{S}}$ & $\stackrel{\overbrace{}}{=}$ & $\stackrel{\vec{i}}{\vec{i}}$ \\
\hline & 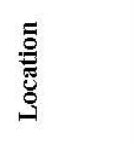 & 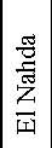 & 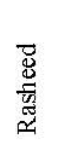 & 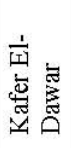 & 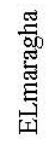 & 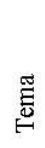 & 茎 & $\begin{array}{l}\frac{8}{8} \\
\stackrel{0}{0} \\
03 \\
03\end{array}$ \\
\hline
\end{tabular}


As for the phosphorus content, the obtained data revealed that pollens of the males of Kafer El-Dawar and Rasheed recorded the highest phosphorus content the differences were statistically significant except with those males of ElMaragha and Tahta in 2009 only. Significant differences were noticed between pollens of the male type that grown in Rasheed and all other male types in the second season. On the other hand, it's clear that pollens of El-Maragha males of recorded a considerable highest value of potassium content in the first season $(1.75 \%)$, and the differences were statistically significant in comparison with the values of all other male types. These findings were confirmed by Bacha et al., (1997) studied the mineral composition of the pollen of some date palm male types and found that the percent of nitrogen ranged between $2.53-2.88 \%$ on the basis of dry weight, as for phosphorus and potassium content, they found the percent varied between $0.82-0.94 \%$ and $0.96-1.11 \%$ for the two elements respectively.

TABLE 4. Mineral contents of the pollen grains of the different male types during 2009 and 2010 seasons.

\begin{tabular}{|c|c|c|c|c|c|c|}
\hline \multirow{3}{*}{ Location } & \multicolumn{6}{|c|}{ Mineral contents } \\
\hline & \multicolumn{3}{|c|}{2009} & \multicolumn{3}{|c|}{2010} \\
\hline & $\begin{array}{c}\mathrm{N} \\
(\%)\end{array}$ & $\begin{array}{c}\mathrm{P} \\
(\%)\end{array}$ & $\underset{(\%)}{\mathrm{K}}$ & $\begin{array}{c}\mathrm{N} \\
(\%)\end{array}$ & $\begin{array}{c}\mathrm{P} \\
(\%)\end{array}$ & $\underset{(\%)}{\mathrm{K}}$ \\
\hline El Nahda & 3.79 & 0.44 & 1.15 & 3.68 & 0.40 & 1.17 \\
\hline Rasheed & 5.08 & 0.38 & 1.36 & 4.91 & 0.50 & 1.09 \\
\hline Kafer El-Dawar & 3.15 & 0.50 & 0.88 & 3.00 & 0.42 & 0.70 \\
\hline El-Maragha & 2.78 & 0.47 & 1.75 & 3.25 & 0.38 & 1.14 \\
\hline Tema & 3.48 & 0.33 & 0.91 & 3.14 & 0.31 & 0.72 \\
\hline Tahta & 3.18 & 0.42 & 1.24 & 2.93 & 0.37 & 1.10 \\
\hline LSD (0.05) & 1.19 & 0.09 & 0.33 & 0.94 & 0.08 & 0.20 \\
\hline
\end{tabular}

Amino acids

Tables $5 \& 6$ represent the amino acid content of pollen grains of the different date palm types in 2009 and 2010 seasons.

As for the Aspartic acid content in the pollens of the different male types, the data concerning this point in 2009 season were tabulated in a descending order (g/100g protein) for the males of El-Maragha, El-Nahda, Kafer El-Dawar, Rasheed, Tahta and Tema. In 2010 season, it was for Kafer El-Dawar, Rasheed, El-Nahda, Tahta, Tema and El-Maragha respectively. However, threonine content, the obtained results showed that, males of El-Maragha recorded the highest values in both season (4.50 and $4.20 \mathrm{~g} / 100 \mathrm{~g}$ protein). On the contrary, males of Tema recorded the lowest values of protein content in both seasons.

For the serine content, it was clear that males of Kafer El-Dawar gave significantly the greatest value in 2009 season (4.90 g / 100g protein). The differences between this male and the males of the other locations, with the 
exception of the males of Rasheed and El-Nahda, were significant. Moreover, glutamic acid content in the pollens of the studied males as arranged in a descending order in 2009 season were: 12.76, 11.58, 11.50,

11.41, 10.78, 10.58, 10.28, 9.62, 9.11 and 8.12 (g / $100 \mathrm{~g}$ protein) for Rasheed, El-Nahda, Kafer El-Dawar, Tema, El-Maragha and Tahta, respectively. However, in 2010 was for males of Kafer El-Dawar, El-Nahda, , El-Maragha, Tema, Rasheed, and Tahta respectively.

Kafer El-Dawar palm males recoded the highest value of proline content, however, the lowest value was observed by El-Maragha location. Concerning the glycine content, Tahta location revealed the highest value in both seasons, however, the opposite was true for El-Maragha location. A remarkable highest alanine contents was noticed for Rasheed males, while, the lowest contents were for Tahta males. On the other hand the cystine content showed that pollens of ElNahda male had the highest values of cystine content in both seasons ( 0.43 and $0.46 \mathrm{~g} / 100 \mathrm{~g}$ protein) and the differences were statistically significant when compared with the values of all other male types.

It is obvious that pollens of El-Maragha male type contained the greatest values of the valine and the methionine in both seasons. For valine, the data of 2009 showed that there were no significant differences between the value recorded for El-Maragha male and the values recorded for the male types of ElNahda, Rasheed and Kafer El-Dawar. In 2010, the differences were not significant between the value recorded for El-Maragha male and the value recorded for the male types of El-Nahda only. On the contrary, the lowest values found in the pollens of Tahta male in both seasons (3.26 and $3.46 \mathrm{~g} / 100 \mathrm{~g}$ protein).

Pollens of Rasheed male showed the heights value of Isolucine in 2010 (6.30 $\mathrm{g} / 100 \mathrm{~g}$ protein), in the meantime, no significant differences were observed when compared with the recorded values in the pollens of El-Maragha and ElNahda males. Meanwhile, the leucine content in the pollens of the different male types, the data concerning this point in 2009 season were tabulated in a descending order for Tahta, Rasheed, Kafer El-Dawar, Tema, El-Nahda and ElMaragha males, respectively. However, in 2010, it was for Rasheed, Tahta, Kafer El-Dawar, Tema, El-Nahda and El-Maragha males, respectively.

Regarding the tyrosine content, the obtained results of both seasons indicated that, pollens of El-Maragha male had the highest tyrosine content (16.96 and $15.96 \mathrm{~g} / 100 \mathrm{~g}$ protein), but there were no significantly differences when compared with the recorded values of Rasheed and Kafer El-Dawar pollens in 2009 only. On the other hand, the lowest value of phenylalanine was obtained by

Egypt. J. Hort. Vol. 40, No.1 (2013) 
pollens of El-Nahda male (3.09 g / $100 \mathrm{~g}$ protein) in 2009, but pollens of Tema male had the lowest phenylalanine content $(3.10 \mathrm{~g} / 100 \mathrm{~g}$ protein) in 2010. Moreover, the obtained data revealed that, pollens of Tema male type had the highest histidine content in both seasons (17.24 and $16.53 \mathrm{~g} / 100 \mathrm{~g}$ protein), and significant differences were observed in comparison with that of the rest of the male types.

Pollens of Rasheed had the highest lysine content in 2009 (6.48 g / $100 \mathrm{~g}$ protein), however, there were no significant differences when compared with those of El-Maragha, Kafer El-Dawar and El-Nahda males. In 2010 pollens of Kafer E-Dawar male recorded had the highest lysine content $(6.50 \mathrm{~g} / 100 \mathrm{~g}$ protein), also there were no significant differences when compared with those El-Nahda, Rasheed and El-Maragha male types. Pollens of El-Maragha male type gave considerable the greatest arginine content in both seasons (5.84 and $5.70 \mathrm{~g} / 100 \mathrm{~g}$ protein),

It seemed that the amino acid contents in the pollens of the studied male types varied from one male to another, such variations could be attributed to the differences in the genetic makeup of the different male types used in the present study and, in some extent, to the diversities in the environmental conditions especially the nutritional conditions - between the locations where the studied males were grown. In this regard, Campos et. al., (2008) stated that seventeen different amino acids may present in pollen loads proline, glutamic and aspartic acids, lysine and leucine are the predominant amino acids, constituting approximately $55 \%$ of the total amino acids. Moreover, Hassan (2008 \& 2011) concluded that, generally, pollen contains all the essential amino acids but the amount may vary from one type to another and the essential amino acids of palm pollen grains were leucine and lysine. Moderate amount of essential amino acids were observed in palm pollen grains, these amino acids were valine, threonine, phenylalanine, histidine and isolucine.

\section{DNA Fingerprint Using RAPD Markers}

Polymorphism as detected by RAPD markers

The polymorphism among 12 male date palm genotypes (from 1 to 4 belongs to El-Nahda, from 5 to 8 belongs to Rasheed and from 9 to 12 belongs to Tema ) was investigated using six RAPD primers. The total number of amplified bands by these six primers was 50 fragments, and the number of amplified DNA fragment by each primer ranged from 7 to 10 fragments. OPL12 amplified the highest number of fragments (10 bands) while, OPD01 and OPL20 produced the lowest number of bands (7). The average number of fragments / primer was 8.3 and the size of these fragments ranged from $250-1500 \mathrm{bp}$.

All the used primers produced polymorphic bands (Table 7). The number of polymorphic was 46 resulting in an average polymorphism / primer of 7.7. Primer OPC13 and OPL12 revealed the highest number of polymorphic bands (9) while, the lowest number polymorphic band (6) was detected by OPM01. 


\begin{tabular}{|c|c|c|c|c|c|c|c|}
\hline 量 & $\begin{array}{l}\infty \\
\dot{+}\end{array}$ & הี & $\begin{array}{l}\text { Sু } \\
+ \\
+\end{array}$ & $\begin{array}{l} \pm \\
\infty \\
\text { in }\end{array}$ & $\underset{i}{\vec{n}}$ & $\underset{+}{+}$ & ले \\
\hline 3 & $\underset{0}{\infty}$ & $\underset{\substack{0 \\
0}}{ }$ & 궁 & m. & $\stackrel{8}{i}$ & $\frac{0}{4}$ & $\stackrel{\text { g. }}{0}$ \\
\hline 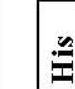 & 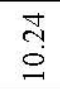 & $\begin{array}{l}\underset{8}{8} \\
\text { i }\end{array}$ & $\begin{array}{l}\text { ț } \\
\stackrel{0}{9}\end{array}$ & $\begin{array}{l}\infty \\
\infty \\
m \\
-\end{array}$ & $\stackrel{\unlhd}{I}$ & ڤે & กี \\
\hline$\stackrel{I}{E}$ & $\begin{array}{l}8 \\
\text { mi }\end{array}$ & $\stackrel{\substack{++}}{ }$ & $\stackrel{\text { gे }}{\circ}$ & $\stackrel{+}{i}$ & $\underset{m}{\vec{m}}$ & $\underset{m}{\stackrel{E}{m}}$ & $\begin{array}{l}\widetilde{0} \\
0\end{array}$ \\
\hline 1 & $\stackrel{\text { P }}{\mathrm{i}}$ & $\begin{array}{l}\infty \\
0 \\
\end{array}$ & $\stackrel{\circ}{\stackrel{\circ}{ \pm}}$ & \begin{tabular}{l}
0 \\
$\stackrel{0}{0}$ \\
\hdashline
\end{tabular} & $\begin{array}{l}8 \\
\dot{g}\end{array}$ & $\begin{array}{l}\stackrel{2}{2} \\
\stackrel{2}{3}\end{array}$ & $\begin{array}{l}\circ \\
\stackrel{2}{0}\end{array}$ \\
\hline - & $\begin{array}{l}8 \\
0 \\
0\end{array}$ & $\begin{array}{l}8 \\
0\end{array}$ & $\begin{array}{l}n \\
0 \\
0\end{array}$ & $\stackrel{?}{\rightarrow}$ & $\begin{array}{l}\infty \\
\text { రి } \\
0\end{array}$ & $\stackrel{8}{\circ}$ & 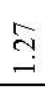 \\
\hline$\underline{-}$ & $\begin{array}{l}? \\
\text { in }\end{array}$ & $\frac{\infty}{0}$ & 吾 & तु & $\stackrel{\stackrel{\sim}{*}}{\rightarrow}$ & $\begin{array}{l}\stackrel{\infty}{+} \\
+\end{array}$ & $\begin{array}{l}q \\
0 \\
0\end{array}$ \\
\hline 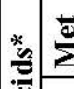 & $\stackrel{8}{\circ}$ & $\stackrel{\infty}{\underset{m}{\longrightarrow}}$ & $\stackrel{\overbrace{}}{\overbrace{}}$ & $n$ & $\stackrel{n}{g}$ & $\stackrel{g}{\mathrm{~g}}$ & సิ \\
\hline 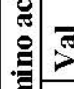 & $\begin{array}{l}8 \\
i \\
\end{array}$ & $\stackrel{5}{+}$ & $\stackrel{8}{+}$ & $\begin{array}{l}\text { gे } \\
\text { in }\end{array}$ & $\begin{array}{l}\infty \\
\stackrel{\infty}{m} \\
\end{array}$ & ì & $\begin{array}{l}8 \\
0 \\
0\end{array}$ \\
\hline 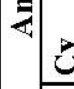 & $\stackrel{m}{\circ}$ & लै & $\overrightarrow{3}$ & $\begin{array}{l}\text { î } \\
0\end{array}$ & $\overrightarrow{3}$ & ले & $\begin{array}{l}\text { J } \\
\stackrel{0}{0}\end{array}$ \\
\hline$\stackrel{\pi}{\pi}$ & $\begin{array}{l}n \\
n \\
n\end{array}$ & $\begin{array}{l}\infty \\
\infty \\
i n\end{array}$ & $\begin{array}{l}8 \\
0 \\
\text { in }\end{array}$ & $\begin{array}{l}\text { nे } \\
\text { in }\end{array}$ & $\begin{array}{l}\infty \\
+ \\
+\end{array}$ & $\stackrel{\text { mे }}{\rightarrow}$ & $\begin{array}{l}\sigma \\
0\end{array}$ \\
\hline$\frac{B}{b}$ & $\begin{array}{l}8 \\
\text { m }\end{array}$ & $\stackrel{\leftrightarrow}{m}$ & $\stackrel{\stackrel{m}{*}}{+}$ & $\stackrel{\vec{m}}{m}$ & $\begin{array}{l}\stackrel{8}{\circ} \\
\end{array}$ & \begin{tabular}{l}
\multirow{J}{*}{} \\
$\stackrel{+}{*}$
\end{tabular} & $\begin{array}{l}\stackrel{\infty}{0} \\
0\end{array}$ \\
\hline 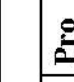 & $\stackrel{\sim}{m}$ & $\begin{array}{l}\vec{D} \\
\infty \\
m\end{array}$ & $\begin{array}{l}8 \\
\text { m }\end{array}$ & $\underset{-}{F}$ & $\underset{ت}{\stackrel{I}{ت}}$ & E & $\begin{array}{l}n \\
0 \\
0\end{array}$ \\
\hline 룬 & $\stackrel{\cap}{=}$ & $\stackrel{\infty}{=}$ & $\stackrel{\exists}{\exists}$ & $\vec{a}$ & $\begin{array}{l}\widetilde{0} \\
\stackrel{0}{\circ}\end{array}$ & $\underset{\infty}{\infty}$ & $\stackrel{\circ}{\circ}$ \\
\hline : & $\begin{array}{l}\text { 导 } \\
\dot{\rightarrow}\end{array}$ & 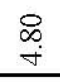 & $\stackrel{8}{+}$ & $\begin{array}{l}\overrightarrow{\mathcal{I}} \\
\dot{f}\end{array}$ & 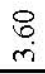 & $\stackrel{R}{m}$ & $\begin{array}{l}n \\
0 \\
0\end{array}$ \\
\hline 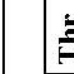 & 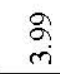 & 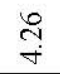 & $\stackrel{\widetilde{m}}{+}$ & $\begin{array}{l}n \\
\rightarrow \\
+\end{array}$ & $\begin{array}{l}\underset{\infty}{\mathcal{N}} \\
\stackrel{i}{i}\end{array}$ & $\underset{m}{m}$ & $\begin{array}{c}\hat{\infty} \\
\dot{0}\end{array}$ \\
\hline$y$ & $\begin{array}{l}8 \\
\mathrm{~m} \\
\end{array}$ & $\stackrel{\Xi}{\Xi}$ & $\begin{array}{l}8 \\
i \\
\end{array}$ & $\begin{array}{l}\stackrel{\leftrightarrow}{\dot{⿰}} \\
\end{array}$ & $\begin{array}{l}n \\
n \\
n\end{array}$ & $\begin{array}{l}\infty \\
\infty \\
0\end{array}$ & $\stackrel{\text { }}{\Omega}$ \\
\hline है & 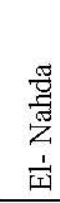 & 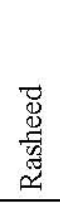 & 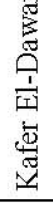 & 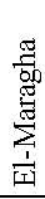 & 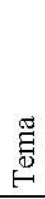 & $\begin{array}{l}\text { 营 } \\
\text { 窇 }\end{array}$ & 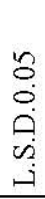 \\
\hline
\end{tabular}

Egypt. J. Hort. Vol. 40, No.1 (2013) 
EVALUATION OF SOME DATE PALM MALE TYPES USING ...

\begin{tabular}{|c|c|c|c|c|c|c|c|}
\hline$\frac{\infty}{3}$ & 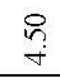 & î & $\begin{array}{l}8 \\
+\end{array}$ & $\begin{array}{l}\stackrel{P}{n} \\
\text { in }\end{array}$ & $\overline{i n}$ & $\stackrel{8}{\stackrel{8}{+}}$ & $\begin{array}{l}F \\
0\end{array}$ \\
\hline 3 & $\frac{\pi}{6}$ & $\begin{array}{l}F \\
0\end{array}$ & $\begin{array}{l}\stackrel{n}{n} \\
0\end{array}$ & $\overrightarrow{0}$ & $\vec{m}$ & $\underset{\sim}{\stackrel{7}{n}}$ & 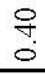 \\
\hline$\cong$ & $\begin{array}{l}\overrightarrow{2} \\
\text { à }\end{array}$ & $\begin{array}{l}\stackrel{8}{0} \\
\text { తi }\end{array}$ & $\stackrel{1}{\circ}$ & $\stackrel{I}{ \pm}$ & 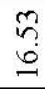 & 궁 & 角 \\
\hline$\frac{2}{E}$ & $\overrightarrow{\mathrm{m}}$ & 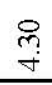 & $\stackrel{\sim}{\rightarrow}$ & $\begin{array}{l}\infty \\
+ \\
+\end{array}$ & $\underset{m}{\stackrel{\circ}{m}}$ & $\stackrel{R}{q}$ & $\hat{0}$ \\
\hline$t$ & $\stackrel{8}{8}$ & $\begin{array}{l}8 \\
0 \\
0\end{array}$ & $\begin{array}{l}\stackrel{0}{2} \\
\stackrel{9}{2}\end{array}$ & 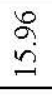 & $\stackrel{\sim}{\stackrel{9}{-}}$ & ลิ & $\begin{array}{l}18 \\
0 \\
0\end{array}$ \\
\hline دـ & $\begin{array}{l}8 \\
0 \\
\end{array}$ & $\begin{array}{l}n \\
0 \\
0\end{array}$ & $\begin{array}{l}5 \\
\text { in }\end{array}$ & 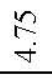 & $\begin{array}{l}? \\
\text { in }\end{array}$ & $\begin{array}{l}8 \\
6 \\
6\end{array}$ & $\stackrel{\cap}{\rightarrow}$ \\
\hline$\cong$ & $\begin{array}{l}8 \\
\text { in } \\
\end{array}$ & లి & 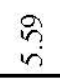 & $\begin{array}{l}\text { हे } \\
\text { nे }\end{array}$ & $\stackrel{5}{\exists}$ & $\stackrel{?}{\stackrel{9}{+}}$ & $\begin{array}{l}\circ \\
0 \\
0\end{array}$ \\
\hline$\sum_{\Sigma}^{ \pm}$ & 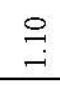 & $\stackrel{m}{m}$ & $\stackrel{\text { ঙ̊ }}{-}$ & $\stackrel{\wp}{-}$ & $\stackrel{\text { f }}{-}$ & $\stackrel{f}{f}$ & సे \\
\hline$\overline{7}$ & $\begin{array}{l}\vec{n} \\
\dot{n} \\
\end{array}$ & 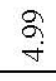 & $\begin{array}{l}\infty \\
\dot{\infty} \\
+\end{array}$ & $\begin{array}{l}8 \\
0 \\
\end{array}$ & $\begin{array}{l}R \\
m\end{array}$ & 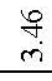 & $\begin{array}{l}3 \\
0 \\
0\end{array}$ \\
\hline 0 & $\stackrel{\circ}{\circ}$ & $\stackrel{m}{m}$ & ?ి & 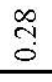 & ते & $\hat{3}$ & $\stackrel{2}{8}$ \\
\hline$\frac{\pi}{4}$ & $\begin{array}{l}\text { ते } \\
\text { in }\end{array}$ & $\begin{array}{l}6 \\
i \\
0\end{array}$ & $\stackrel{\infty}{\stackrel{\infty}{+}}$ & $\stackrel{\leftrightarrow}{\leftrightarrow}$ & $\underset{f}{f}$ & خे & $\stackrel{8}{\circ}$ \\
\hline 룬 & $\begin{array}{l}8 \\
\dot{m}\end{array}$ & $\begin{array}{l}\frac{12}{7} \\
+\end{array}$ & 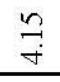 & $\begin{array}{l}: \\
\dot{m}\end{array}$ & $\stackrel{\text { in }}{\rightarrow}$ & 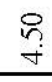 & 品 \\
\hline$\stackrel{2}{2}$ & 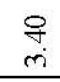 & $\stackrel{12}{m}$ & $\begin{array}{l}P \\
m \\
\end{array}$ & $\stackrel{\overbrace{}}{\rightarrow}$ & $\stackrel{8}{-}$ & $\stackrel{?}{I}$ & $\begin{array}{l}8 \\
0 \\
\end{array}$ \\
\hline 큰 & 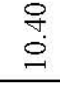 & $\begin{array}{l}\infty \\
? \\
\end{array}$ & $\underset{\stackrel{\vec{\sigma}}{\circ}}{\mathrm{-}}$ & 궁 & $\begin{array}{l}8 \\
0 \\
\end{array}$ & $\stackrel{\text { ro }}{r}$ & $\stackrel{ }{=}$ \\
\hline 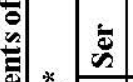 & $\stackrel{m}{\forall}$ & $\stackrel{n}{\circ}$ & 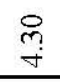 & $\underset{\forall}{\stackrel{Ð}{\forall}}$ & $\stackrel{n}{m}$ & 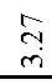 & $\stackrel{\infty}{+}$ \\
\hline 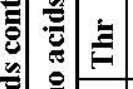 & $\stackrel{ }{;}$ & $\stackrel{2}{\rightarrow}$ & $\begin{array}{l}\exists \\
\dot{+}\end{array}$ & 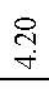 & S & $\begin{array}{l}\stackrel{8}{0} \\
\stackrel{m}{2}\end{array}$ & $\begin{array}{l}\stackrel{0}{\circ} \\
0\end{array}$ \\
\hline 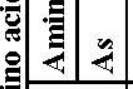 & $\stackrel{8}{=}$ & $\stackrel{8}{\text { తi }}$ & $\stackrel{n}{m}$ & $\begin{array}{l}8 \\
\infty \\
\infty\end{array}$ & $\begin{array}{l}8 \\
2 \\
2\end{array}$ & $\begin{array}{l}\text { f. } \\
\stackrel{0}{9}\end{array}$ & $\vec{\sim}$ \\
\hline 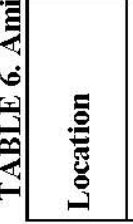 & 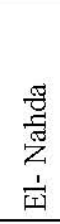 & 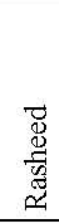 & 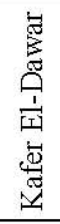 & 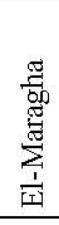 & 莺 & 莺 & 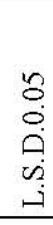 \\
\hline
\end{tabular}

Egypt. J. Hort. Vol. 40, No.1 (2013) 
Therefore, the percent of polymorphism revealed by the different primers ranged from $75 \%-100 \%$.

In this respect, Abdalla and Gamal (2010) investigated some date palms using RAPD technique, the obtained fragments ranged from $300-3000 \mathrm{bp}$, and the average number of amplified bands was five and all of the tested genotypes revealed a unique profile.

TABLE 7. The total number of bands; monomorphic bands, polymorphic bands and percentage of polymorphism as revalues by RAPD markers among 12 date male genotypes.

\begin{tabular}{|l|c|c|c|c|}
\hline Primers & $\begin{array}{c}\text { Total } \\
\text { number of } \\
\text { bands }\end{array}$ & $\begin{array}{c}\text { Monomorphic } \\
\text { bands }\end{array}$ & $\begin{array}{c}\text { Polymorphic } \\
\text { bands }\end{array}$ & $\begin{array}{c}\text { percentage of } \\
\text { polymorphism }\end{array}$ \\
\hline OPC13 & 9 & - & 9 & 100 \\
OPD01 & 7 & - & 7 & 100 \\
OPL12 & 10 & 1 & 9 & 90 \\
OPL20 & 7 & - & 7 & 75 \\
OPM01 & 8 & 1 & 8 & 88.8 \\
OPZ01 & 9 & 4 & 46 & 553.8 \\
\hline Total & 50 & 0.66 & 7.7 & 92.3 \\
\hline Mean & 8.3 & & & \\
\hline
\end{tabular}

Cluster analysis as revealed by RAPD marker

The Dice RAPD-based coefficient of genetic similarity among the 12 genotypes of male date palm resulted in a dendrogram (Fig.1), which separated genotype 1 from all the other male date palm genotypes, thus demonstrating the distinctiveness of the genetic background of genotype 1 from all the other genotypes. The other male date palm cluster comprised two subclusters. One subcluster was divided into two groups the first included genotype 9. While, the other group was divided into three subgroups. Both of genotype 8 and 7 was grouped together, reflecting common genetic background, meanwhile genotypes 10,11 and 12 were clustered together in one subgroup. On the other hand, the second subcluster was divided into three groups. Genotypes 1 and 6 were grouped separately from the other genotypes in the second subcluster. However, the third group was divided into two subgroups, one of these subgroups included genotype 4, while the other one included genotypes 3 and 5. Motawei et al. (2003), constructed a dandrogram using UPGMA analysis from PAPD marker with five date palm cultivars (Barhi, Nabet Ali, Rothanah, Ajwa and Sokkari), and on the basis of analysis, the populations were clustered into two clusters: cluster I contained Bachi and Ajwa cultivars, and cluster $\Pi$ contained Nabet Ali, Rothanah and Sokkari cultivars. Whereas, the RAPD based dendrograms clustered the accessions belonging to each of the 3 cultivars Fraihy, Siwi and Gandila in separate groups. However, the reshuffling in the position of the

Egypt. J. Hort. Vol. 40, No.1 (2013) 
accessions belonging to the other cultivars in the different dendrograms revealed that they share common genetic background (Hussein et al., 2004).

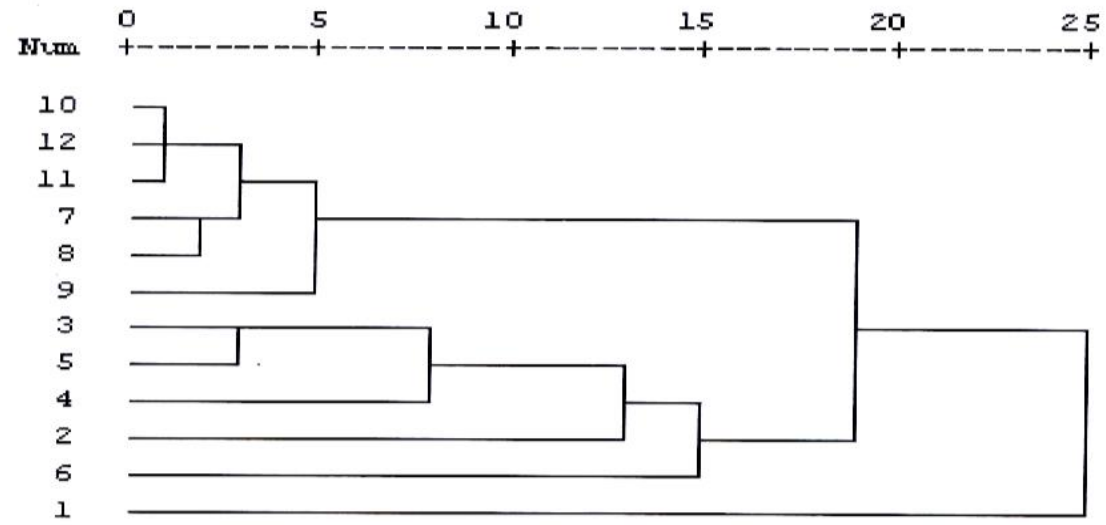

Fig. 1. Dendrogram of correlation similarity using average linkage (Between Groups) among the different male types based on RAPD results.

Genotype Identification by unique RAPD markers

In the present study, genotype-specific RAPD unique markers could distinguish 4 out of the 12 date palm genotypes. The RAPD primers generating the markers and the markers approximate size are shown in Table (8). Among these four genotypes, genotype 1 was characterized by both positive and negative unique RAPD markers. However, the other three genotypes were characterized by only positive or negative unique markers. Genotype 4 and genotype 6 showed only one unique negative marker at 875 bp, 537 bp with OPC13 and OPL12 primers, respectively. On the other hand, genotype 9 was characterized by two unique positive markers at $540 \mathrm{bp}, 355 \mathrm{bp}$ with OPC13. Genotype 1 was characterized by one unique negative marker at 1335 bp with OPZ01, while it characterized by four positive unique markers at $950 \mathrm{bp}$ (OPL20), 1240 bp (OPZ01) and 1450 and 450 bp (OPC13). The primer (OPC13) has the potential to identify three out of the four characterized genotypes. Thus, only four primers characterized four genotypes out of the twelve tasted date palm male, however, if more primers were examined, more markers would be expected.

In this respect, Motawei et al. (2003) demonstrated that RAPD polymorphism and reproducibility within five date palm cultivars (Barhi, Nabtel Ali, Rathanat, Ajwa and Sokkri) suggest that RAPD markers can be used successfully for varietals. Identification and for studying the genetic diversity of cultivars. Moreover, Hussein et al. (2004) characterized 4 cultivars out of six date palm cultivars (Sakkoty, Bertmoda, Malkaby, Gandila, Fraihy and Siwi) when used 27 RAPD primers. 
TABLE 8. Unique positive and negative markers that characterized the studied date palm male genotypes.

\begin{tabular}{|c|c|c|c|c|c|c|}
\hline \multirow[b]{2}{*}{$\begin{array}{c}\text { Genotype } \\
\text { number }\end{array}$} & \multicolumn{3}{|c|}{ Unique positive markers } & \multicolumn{3}{|c|}{ Unique negative markers } \\
\hline & $\begin{array}{l}\text { Size of the } \\
\text { marker } \\
\text { band } \\
\text { (bp) }\end{array}$ & primer & $\begin{array}{c}\text { Total } \\
\text { number of } \\
\text { Markers / } \\
\text { genotype }\end{array}$ & $\begin{array}{l}\text { Size of the } \\
\text { marker } \\
\text { band } \\
\text { (bp) }\end{array}$ & primer & $\begin{array}{c}\text { Total } \\
\text { number of } \\
\text { Markers / } \\
\text { genotype }\end{array}$ \\
\hline 1 & $\begin{array}{c}950 \\
1240 \\
1405-450 \\
\end{array}$ & $\begin{array}{l}\text { OPL20 } \\
\text { OPZ01 } \\
\text { OPC13 } \\
\end{array}$ & 4 & 1335 & OPZ01 & 1 \\
\hline 4 & - & - & - & 875 & OPC13 & 1 \\
\hline 6 & - & - & - & 537 & OPL12 & 1 \\
\hline 9 & $540-355$ & OPC13 & 2 & - & - & -- \\
\hline
\end{tabular}

\section{References}

Abdulla, M. and Gamal, O. (2010) Investigation on molecular phylogeny of some date palm (Phoenix dactylifera $\mathrm{L}$ ) cultivars by protein, RAPD and ISSR markers in Saudi Arabia. Australian Journal of Crop Science (ASUS), 4(1), 23 - 28.

Agricltural Statistics (2008) Ministry of Agricultural and land Reclamation, Egypt. Vol. $2 \mathrm{~h}$.

Alsaikhan, M.S. (2006) Physical and chemical characteristics response of three date palm cultivars to source of pollen grains, J. Agric. Sci. Monsoura Univ, 31 (3), 1637-1546.

Ashour, N. E, Hassan, H.S.A. and Mostafa, E.A. (2004) Yield and fruit quality of Zaghloul and Samony date palm (Phoenix dactylifera L.) as affect by pollination method. Annals of Agric. Cairo, 49 (2), 6631:642.

Association of American Chemis. (A.O.A.C). (1981) Offical Methods of Analysis $22^{\text {nd }}$ ed. Washington, D. C., U. S. A.

Bacha, M.A, Ali, M.A. Farahat, F.A. (1997) Chemical composition of pollen grains of some date palm males grown in Riyadh Saudi Arabia. Arab. Gulf J. Scient. Res., 15 (3), 783-803.

Badawi, F.M. Meawads and Mourad, K.T. (1994) Growing a Prodution of date palm Egyption Agriculture Bull No.2 / 8 / 1994.

Campos, M.G.R., Bogdanov, S., de Almeida-Muradian, L.B., Szczesna, T., Mancebo, Y., Frigerio, C. and Ferreira, F. (2008) Pollen composition and standardization of analytical methods. Journal of Apicultural Research and Bee World, 47(2), 156-163.

Dubois, M. Giles, K.A., Hamilton, J.K., Roberand and P.A. Smith, F. (1956) Colorimetric method for determination of sugar and related substances. Analytical chemistry, 28, 350-356.

Egypt. J. Hort. Vol. 40, No.1 (2013) 
El-Hammady, M.M., Khalifa, A.S. and Al-Hammady, A.M. (1977) The effect of date pollen on some physical and chemical character of Hayani Variety. Reserch Bulletin. 737, Fac. Agric, Ain Shams Univ. Cairo.

El-Maktoun, F.M. B. (1981) Effect of different pollen types on fruiting and fruit quality in some date varieties. M. Sc. Thesis. Fac. Agric., Al-Azhar University.

Evenhuis, B. and Dewaard, P.W. (1980) Principles and practices in plant analysis. FAO Soils Bull., 38 (1), 152-163.

Hamdy, Z.M. (1982) Effect of source of pollen on the physical quality of amhat date variety. Agric. Res. Rev., 60, 5-22.

Hassan, H.M.M. (2008) Biochemical characterization of palm pollen extracts as biostimulator in different systems. Ph.D. Thesis, Cairo University, Giza, Egypt.

Hassan, H.M.M. (2011) Chemical composition and nutritional value of palm pollen grains. Global Journal of biotechnology and biochemistry, 6 (1), 1 - 7.

Human, H. and Nicolson, S.W. (2006) Nutritional content of fresh, bee - collected and stored pollen of Aloe greatheadii var. davyana (Asphodelaceae) Photochemistry, 67, $1486-1492$

Hussein, E.H., Adway, S.S. Ismail, S.E. and El-Itrriby, H.A. (2004) Molecular characterization of some Egyptian date palm germplasm using RAPD and ISSR markers. Arab. J. Biotech., 8 (1), 83-98.

Ibrahim, A.M.F. (1989) Germination of date palm (Phoenix dactylifera L.) J. Agric. Sci. Mansoura Univ., 14, 1729-1733.

Ibrahim, A.M. and Kholif, M.N. (2004) Date palm production in Egypt and Arab World Monshaat Al-Maarif, Alexandria, Egypt (In Arabic).

Khalifa, A., Azzouz, S., Hamdy, Z.M., Al-Marsy, H. and Yousof, M. (1980) Effect of source of pollen on the physical and chemical quality of Amhat date Variety. Agriculture Researc Review 48, 15-23.

Machado, M.A., Coletta, F.H., Targon, M.L. and Pompeu, J.J. (1996) Genetic relationship of Mediterranean mandarin (Citrus deliciosa Tenore) using RAPD markers. Euphytica, 92, 321-326.

Malik, C.P. and Singh, M.B. (1980) Plant Enzymology and Histroenzymology. A Text Manual. Kalyani Publishers, New Delhi.

Moore, S., Spackman, H.D. and Stein, W.H. (1958) Chromatography of amino acids on sulphonated polystyrene serins: An improved method. Anal. Chem. 30, 1185-1190.

Motawei, M.I., Al-Moshileh, A., Al-Wasel, A. and Abdel-Ltif, T. (2003) Identification of some date palm (Phoenix dactylifera L.) cultivars in Saudi Arabia using RAPD fingerprints. Proceedings of the International Conference on Date palm and Joint Events, King Saudi Univ. Branch El-Qaseem, Sept.16-19, pp . 41-47. 
Nasr, T.A., Shaheen, M.A. and Bacha, M.A. (1986) Evaluation of seedling male palm used in pollination in the central region. Saudi Arabi. Date palm Journal, 4 (2), 163173.

Nielson, G. (1985) The use of isozymes as probes to identify and label plant varieties and cultivars. In: M.C. Rattazzi, J.G. Scandalios, G.S. Whitt (Ed.), Isozymes: Current Topics in Biological and Medical Research. 12, 1 - 32. Alan. R. New York.

Popenoe, P. (1973) The date palm. Field Research Projects Cocount Grove, Miami, Florida.

Porebski, S., Bailey, L.G. and B.R. Baum, (1997) Modification of a CTAB DNA extraction protocol for plants containing high polysaccharides and polyphenol compounds. Plan Mol. Bio. Rep., 15, 8-15.

Rabie, I. S. (2007) Evalution of date palm males used in pollination in Rasheed Region, Egypt. Alex. J. Agric. Res., 52 (1), 91-102.

Snedecor, G. and Cochran, W.G. (1981) Statistical Methods, Ames, Iowa, USA.

Welsh, J. and Mccelland, M. (1990) Fingerprinting genomes using PCR with arbitrary primers. Nucleic Acid Res., 18, 7213-7218.

Williams, J.G., Kublik, A.R., Livak, K.J., Rafalsky, J.A. and Tingey, S.V. (1990) DNA polymorphisms amplified by arbitrary primers are useful as genetic markers. Nucl. Acid. Res., (18), 653-655.

Zohary, D. and Spiegel-Roy, P. (1975) Biginning of fruit growing in the old world. Science. 187, 319-327.

(Received 4/3/2013 ;

accepted $2 / 5 / 2013$ ) 
تقيم بعض الطرز المذكرة لنخيل البلح باستخدام الواسيمات المور فولوجية و الجزيئية

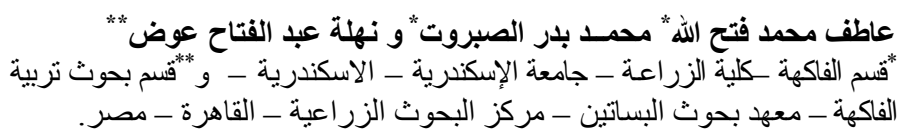

خمس مو اقع لاشجار ذكور النخيل البالغة من ثلاث محافظات (الاسكندرية، البحيرة

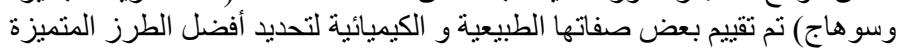

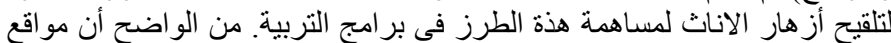

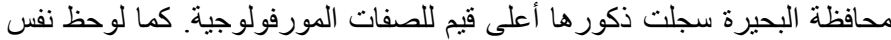

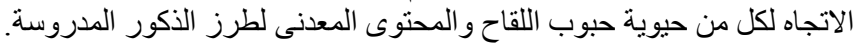

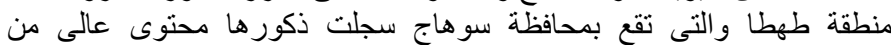

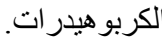

من ناحية أخرى، كانت أعلى نسبة بروتينات مسجلة لذكور منطقة رشيد، في حين

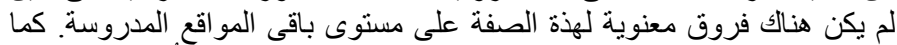

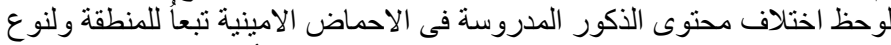

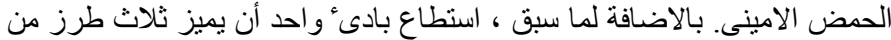

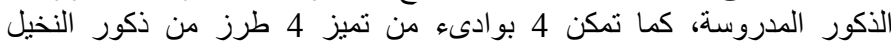
المدروسة.

من هذه الدراسة يتضح ان افضل الذكور المدروسة تلك النامية بمنطقة رشيد

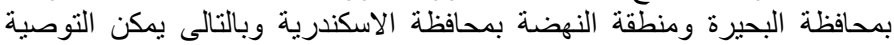

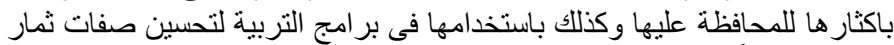

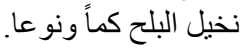

